\title{
SYNTHESIS AND PROPERTIES OF NEW NANOSYSTEMS OF ARGENTUM
}

\section{O. S. Berezhnytska ${ }^{1,2 \star}$, V. S. Semeniv ${ }^{1,2}$, K. A. Sikorska ${ }^{2}$, T. A. Kamenska ${ }^{2}$, L. A. Khrokalo ${ }^{2}$, O. K. Trunova ${ }^{1}$}

${ }^{1}$ V. I. Vernadsky Institute of General and Inorganic Chemistry of the Ukrainian NAS, prospekt Palladina 32/34, 03142 Kyiv, Ukraine

${ }^{2}$ National Technical University of Ukraine «Igor Sikorsky Kyiv Polytechnic Institute», prospekt Peremohy 37, 03056 Kyiv, Ukraine

*e-mail: olekberez@gmail.com

AgEDTA complexonate was synthesized, the manner of coordination of the Argentum (I) ion to the functional groups of complexone was determined. It was found that the solid complex precipitates from the solution in the form of a fine powder. It is shown that the size and shape of nanoparticles of Argentum complexonate depend on the solvent-precipitator. A stable dispersed system based on the synthesized complexonate was obtained. The shape and position of the surface plasmon resonance bands confirm the presence of spherical nanoparticles with a size of 15-30 nm in both dispersed systems. Investigations of the biological activity of the powder of AgEDTA has shown that it has a high bactericidal effect against gram-positive bacteria.

Keywords: nanosystem, Argentum, EDTA, complexonate, bactericidal effect.

INTRODUCTION. The unquenchable interest in nanomaterials and nanosystems is due to their unique properties and the possibility of targeted synthesis of such materials, in particular nanoparticles with required size and predicted properties [1]. Increasing the resistance of pathogenic microorganisms to antibiotics and fungicides is the main problem of medicine. It is well known that silver compounds are active against 16 major species of microorganisms without damaging the beneficial microflora, which increases the interest of scientists in their study $[2,3]$.
For many years in a row, the study of the physicochemical and pharmacological properties of precious metals, in particular gold and silver, has been topical. Whereas the use of gold compounds is limited due to the ambiguity of its properties, in particular toxicity [4-7], the antimicrobial properties of silver are not in doubt. To use nanoparticles in pharmaceutics, it is important to consider the composition of the starting system to avoid additional toxic effects.

There are many publications on the synthesis of silver nanoparticles, the study of their physical, chemical, and biological properties. 
These characteristics depend on many factors, such as the choice of the method of production, stabilizer and reducing agent, the size and morphological shape of the obtained particles [8-10]. Despite the wide range of research results presented, obtaining stable silver-based nanomaterials remains a challenge for researchers.

Depending on the size, silver nanoparticles can be used as catalysts, bactericidal coatings for medical devices and water filters, drug delivery media, electronic components, and biosensors, like preservatives and active ingredients in cosmetics, light filters in optics, and as antibacterial and therapeutic agents in medicine [11-15].

The silver nanoparticles can enter the human organism in a variety of ways, such as through the skin, orally, by inhalation, and injection, with different effects. Although the toxicity of silver nanoparticles is also controversial, the long-term use of AgNPs in various industries proves its safety [16-18].

The researchers' attention to the green synthesis of AgNP is due to the effectiveness and environmental friendliness of this method. The reducing biological agent, which also acts as a stabilizer, is the main requirement of this synthesis. By selecting the plant extract, it is possible to obtain nanoparticles of the desired size. However, the disadvantages of this method are that biological reagents can contain many secondary compounds and metabolites, temperature restrictions inherent in enzymes. The consequence of thise is a low synthesis yield $[19,20]$.

Evaporation-condensation and laser ablation techniques are popular among the physical methods. Both methods allow obtaining nanoparticles of uniform size and high purity, be- cause they do not require the use of additional solvents, which can also emit toxic substances. However, such a synthesis requires cumbersome equipment and high energy costs. The agglomeration of the obtained AgNPs is also observed due to the absence of stabilizers in these methods $[21,22]$.

The most developed and diverse are chemical methods of obtaining silver nanoparticles, among which electrochemical synthesis predominates, which allows one to control the size of nanoparticles by regulating the parameters of electrolysis; sonodecomposition using ultrasonic waves; synthesis in aqueous foams as a matrix; radiolysis; microwave synthesis, which allows one to obtain stable systems at the high concentration of AgNPs at the same temperature and exposure, and others that allow one to obtain nanoparticles with a size in the range of 5-90 nm. A common approach to synthesis is the reduction of silver from its salts using a variety of organic solvents. Thus, particles are obtained, which are usually dispersed in an aqueous medium and require stabilization with surfactants $[23,24]$.

However, some methods do not require the use of an additional stabilizer. These are the Turkevich method or the citrate method, the reduction of ionic silver with glucose, as well as with the help of complexones. The use of simple techniques that do not require additional complex equipment is the best way to solve the problem of synthesis of nanoparticles of required size both from a practical and an economic point of view [25-28].

Complexones are polydentate ligands, organic chelating compounds consisting of amino acid elements. These compounds are widely used in medicine because they are a transporting agent. Important among the complexones 
are nitriloacetic acid (NTA), ethylenediaminetetraacetic acid (EDTA), and its structural isomer ethylenediaminedisuccinic acid (EDDS).

The chelating agent increases the bioavailability of the metal, promotes its accumulation, and increases biological activity. The main task of this work is the synthesis of silver complexonates, their conversion to the disperse state, and the synthesis of colloidal solutions by the reduction of silver with complexones. This synthesis does not require an additional stabilizer, because the complexones have a diphilic structure, ie are surfactants. The complexes of d-metals based on complexones are characterized by a good solubility in water, high stability, and easy digestibility. The advantage of complexones is that they are excreted from the organism in an unchanged state, which significantly depends on the stability of the complexone [29-31]. Besides, it was shown [32-35] that the use of EDTA as a reducing agent in chemical condensation allows one not only to stabilize the system but also to control the particle size depending on the solution $\mathrm{pH}$. Thus, it is of interest to determine correlations between the properties of Argentum (I) complexonate and disperse systems obtained by the reduction of Argentum nitrate with $\mathrm{Na}_{2}$ EDTA solution.

EXPERIMENT AND DISCUSSION OF THE RESULTS

The synthesis was performed in aqueous solutions at a concentration of the starting components of $5 \cdot 10^{-2} \mathrm{M}$ and a ratio of the starting components of 1:2 and 2:1, metal salt $\left(\mathrm{AgNO}_{3}\right)$ and complexone $\left(\mathrm{Na}_{2} \mathrm{EDTA}\right)$, respectively, $\mathrm{pH}=7-8$. The choice of concentration is due to the reduction processes that occur at high concentrations, and $\mathrm{pH}$ of solutions. The complexes were precipitated from the solution with acetone or alcohol, filtered off and dried in a vacuum desiccator over calcium chloride (in a dark place). A white $\mathrm{Na}_{3}[\mathrm{AgEDTA}]$ precipitate separated from the solution during precipitation and turned pink after filtration. The dry precipitate has a dark brown color due to the reduction of surface ions of silver.

The synthesis of disperse systems was performed in aqueous solutions at a ratio of starting components of 1:2, 1:3, 1:5, 2:1, 2:5 for $\mathrm{AgNO}_{3}: \mathrm{Na}_{2}$ edta, respectively. Diluted solutions with a concentration of starting the components of $5 \cdot 10^{-4}, 5 \cdot 10^{-3}, 2.5 \cdot 10^{-4}, 1 \cdot 10^{-3} \mathrm{M}$ were chosen for the study because the necessary condition for obtaining highly disperse heterogeneous systems is to carry out reactions in dilute solutions, and an excess of one of the reagents. In the course of the study it was found that the optimal concentration of solutions is $5 \cdot 10^{-3} \mathrm{M}$. A solution of Argentum nitrate was gradually added to $\mathrm{Na}_{2}$ EDTA solutions under heating and with a magnetic stirrer, the $\mathrm{pH}$ was adjusted with a $0.1 \mathrm{M} \mathrm{NaOH}$ solution and maintained at $8-8,5$. The solutions were stirred at $60^{\circ} \mathrm{C}$ for 60 minutes.

An IR spectrum was recarded to determine the manner of coordination of Argentum to EDTA. The IR spectra were recorded on a Specord M80 spectrometer in a range of $400-4000 \mathrm{~cm}^{-1}$ in tablets with $\mathrm{KBr}$.

The absorption spectra of solutions were recorded on a Specord M40 spectrophotometer in a range of $300-600 \mathrm{~nm}$.

Distribution diagrams of the obtained nanosystems were investigated by the method of dynamic light scattering on «ZetaSizerMalvern».

The powder micrographs were taken on a Hitachi H-800 scanning electron microscope.

The antibacterial effect of the complex was determined on a powder sample of AgEDTA. 
The test was performed by the disk-diffusion method on a solid culture medium (agar). Strains of Bacillus subtilis UKM B-5006 ${ }^{\mathrm{T}}$ (gram-negative spore-forming bacterium) and Escherichia coli UKM B-906 (gram-negative rod-shaped bacterium) were used as experimental cultures. The inoculants were obtained the day before the test on a liquid culture medium, meat-peptone broth $(\mathrm{BCH})$, followed by dilution with a sterile physiological solutions. The density of the inoculant was adjusted to 0.5 on the McFarland scale. The Petri dishes with agar were inoculated with cultures and filter paper disks moistened with distilled water and an AgEDTA powder sample were spread over the inoculated surface. The culture medium was incubated at $37^{\circ} \mathrm{C}$ for three days. The size of the zones of inhibition of bacterial growth was measured with a caliper in $\mathrm{mm}$.
Analysis of the IR spectra indicates that the undissociated carboxyl group is not involved in the complexation process. In the spectra of the complex there is a shoulder at $1660 \mathrm{~cm}^{-1}$, which corresponds to the valence vibrations of uncoordinated $(\mathrm{COOH})$ groups.

In the complexonate spectra, the bands $v^{\text {as }}\left(\mathrm{COO}^{-}\right)$and $v^{\mathrm{s}}\left(\mathrm{COO}^{-}\right)$in the region of 1310 $1400 \mathrm{~cm}^{-1}$ and $1500-1600 \mathrm{~cm}^{-1}$ are significantly shifted to the low frequencies relative to the free ligand, which indicates the formation of bonds of metal ions to dissociated carboxyl groups. The splitting of the band $v^{\mathrm{s}} \mathrm{COO}^{-}$indicates the non-equivalence of carboxyl group binding and different covalent and donor-acceptor bonding mechanisms [36]. The difference in the position of the bands $v^{\mathrm{s}}\left(\mathrm{COO}^{-}\right)$ and $v^{\mathrm{as}}\left(\mathrm{COO}^{-}\right)\left(\Delta v \sim 200 \mathrm{CM}^{-1}\right)$ indicates their monodentate coordination to the metal ion.

Table 1 Assignment of frequencies in the IR spectrum of metal complexonates

\begin{tabular}{|c|c|c|c|c|c|c|c|c|c|}
\hline & $v_{(\mathrm{M}-\mathrm{N})}$ & $v_{(\mathrm{M}-\mathrm{O})}$ & $v_{(\mathrm{CC})}$ & $v_{(\mathrm{CN})}$ & $v_{\text {COO- }}^{s}$ & $\delta_{(\mathrm{CH} 2)}$ & $v_{\text {CoO- }}^{\text {as }}$ & $v_{\mathrm{COOH}}$ & $v_{\mathrm{H} 2 \mathrm{O}}$ \\
\hline AgEDTA & $\begin{array}{l}480,445 \\
390\end{array}$ & $\begin{array}{l}540,565, \\
582,610\end{array}$ & $\begin{array}{l}920 \\
875\end{array}$ & 1120 & $\begin{array}{l}1400 \\
1340\end{array}$ & $1450_{\text {пл }}$ & $\begin{array}{l}1582, \\
1640_{\text {sh. }}\end{array}$ & $1660_{\mathrm{sh}}$. & $\begin{array}{l}3410 \\
3288_{\mathrm{sh}}\end{array}$ \\
\hline $\mathrm{Na}_{2} \mathrm{EDTA}$ & - & - & $\begin{array}{l}920 \\
860\end{array}$ & 1095 & 1436 & 1460 & 1640 & 1670 & 3408 \\
\hline
\end{tabular}

$5 \cdot 10^{-3} \mathrm{M}$ aqueous solutions of complexonates were prepared for investigation of them by the absorption spectroscopy method. Upon dissolution, the complexonates form dark orange solutions. The color of the solution is due to the complexing central ion and the dispersion of the obtained systems. The presence of a surface plasmon resonance (SPR) band in the electron absortion spectra, which is a collective oscillation of metal particles smaller than the wavelength of electromagnetic radiation, indicates the presence of nanoparticles. From the shape and position of this band, we can conclude about the dispersion, shape, and size distribution of nanoparticles. In Fig. 1, the maximum of the SPR band at $\sim 410 \mathrm{~nm}$ indicates a high dispersion of the system. The particle size is in the range of $10-20 \mathrm{~nm}$. The position of the band indicates the sphericity of the particles. 


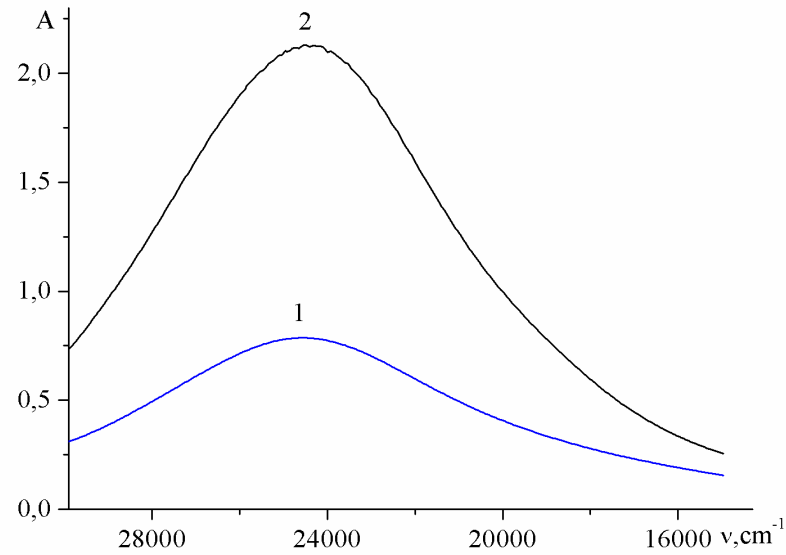

Figure 1 SPR bands of AgEDTA 1-3 hours, 2-21 day.

It is known that disperse systems are characterized by both habituation and aging. To analyze the aggregative stability of the systems, they were studied for a long time. After 3 weeks, the color of the solution became more saturated, however, as can be seen from Fig.1. (curve 2), the maximum of the band shifted by $5 \mathrm{~nm}$ to the long-wavelength region, which indicates the recrystallization of small particles with their subsequent adsorption on larger particles. For the most part, when a critical concentration of micelle formation is reached, smaller spherical particles are formed, which are thermodynamically more stable and less prone to coagulation. If the reduction processes continue in the system, the concentration of particles will increase, which, in turn, will promote coagulation and cause the particles to enlarge, possibly with the formation of ellipses or nanofibers $[35,37,38]$.

The shape of the band has changed, and it has become narrower, which indicates the prevailing radius of particles of the same size and the habituation of the disperse system. The increase in intensity indicates an increase in the number of nanoparticles in the system, that is, about the "maturation» of the colloidal solution. For the solutions prepared with EDTA, the particle size was large, but the band was much narrower, which indicates a smaller distribution of nanoparticles by radius. For cooling solutions of silver (I) disperse systems obtained by reduction with EDTA, the electronic absorption spectra are shown in Fig. 2. The shape and position of the surface plasmon resonance (SPR) band substantially depend on the concentration and time [38].

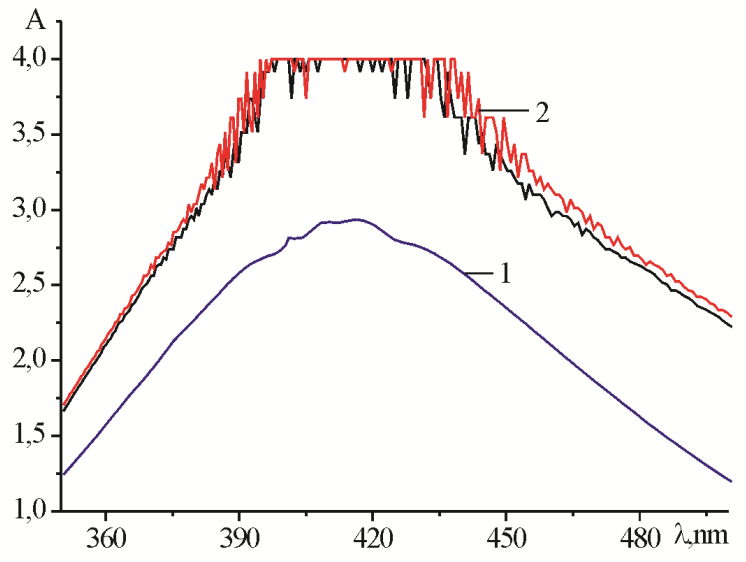

$a$

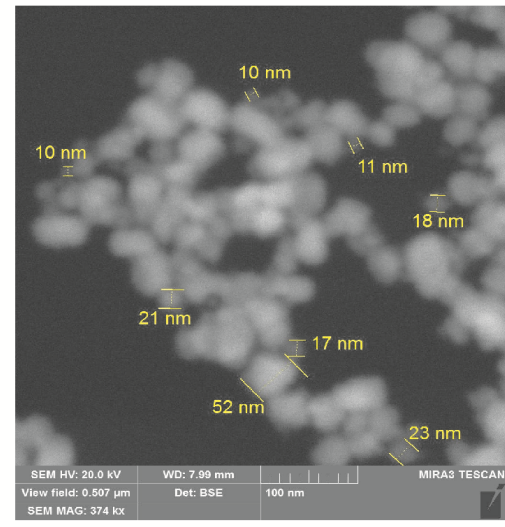

b

Figure 2 SPR band for 0.005M solutions of the system (AgNO3): Na2EDTA after 7, 10 and 14 days (a) micrograph of the system after 14 days, scale mark $100 \mathrm{~nm}$ 
With an increase in the complexone concentration in the system, the particle size and polydispersity of the system increase, therefore, to obtain stable dispersions, the concentration of the initial components should not exceed $5 \cdot 10^{-3} \mathrm{M}$. This is due to the high reducing ability of EDTA. The studies carried out showed that the systems remained stable for a long time, and with time the SPR band became narrower, and the maximum became clearer (Fig. 2).

Within 2 months from the moment of synthesis, the shape and position of the SPR band and the color of the solution did not change. The position of the maximum and the width of the SPR band of the complexonate solution and the colloidal solution were different, which indicates a different shape and size of nanoparticles. This may be due to different micelle formulas and different charge of the colloidal particle.

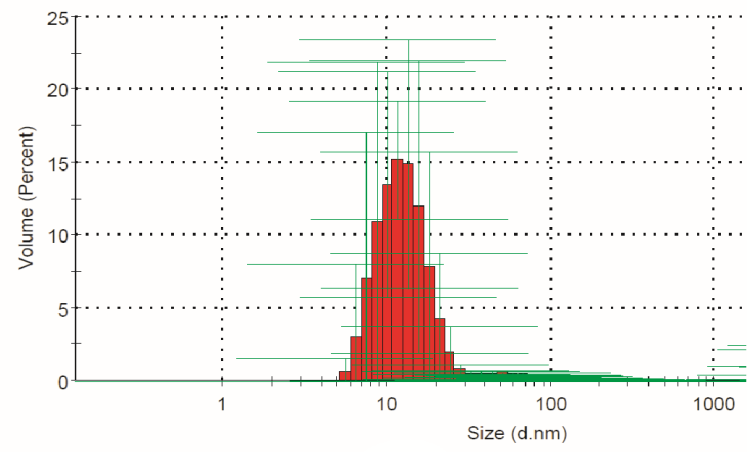

$a$

Schematically, the formation of silver nanoparticles can be written as follows, based on the high reducing properties of EDTA [39-41]:

$$
\mathrm{Ag}^{+} \stackrel{\mathrm{h} v}{\longrightarrow} \mathrm{Ag}^{0}
$$

For the same reasons, a problem arises when writing the micelle formula. Based on the classical approach, if silver is reduced to form metal nanoparticles, the micelle formula has the following form:

$$
\left\{\mathrm{mAg} \mathrm{nAg}^{+}(\mathrm{n}-\mathrm{x}) \mathrm{NO}_{3}^{-}\right\}^{\mathrm{x}+} \mathrm{X} \mathrm{NO}_{3}^{-} \text {. }
$$

In the case of a complexonate solution, we can assume the reduction of surface molecules, where a complex ion acts as a stabilizer, and then a micelle can be depicted as follows:

$$
\left\{\text { mAg nAgedta }{ }^{3-3}(\mathrm{n}-\mathrm{x}) \mathrm{Na}+\right\}^{3 \mathrm{x}-3 \mathrm{x} \mathrm{Na}} \mathrm{Na}^{+}
$$

An analysis of the distribution diagrams (Fig. 3) shows the nanodispersity of the system with the predominant radius of particles of the same size.

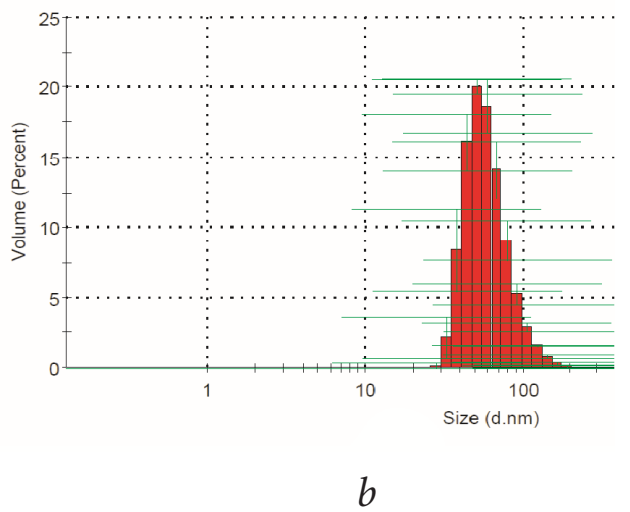

Figure 3 Diagrams to the distribution of particles behind the AgEDTA after 1 day (a), after 21 day (b).

We can state the uniform distribution of the dispersed phase in the dispersion medium. As can be seen from the diagram, at first small particles prevail in the system; after 21 days, the particle size in the system increases, which is due to the recrystallization of small particles, but the system is stable.

The particles absorbing in the range of 410-440 nm have a characteristic spherical shape, which is confirmed by micrographs. 
As can be seen from the micrograph of the pre-dried solution (Fig. 4), even when the sample dries, the nanoparticles do not agglomerate, but retain their original size and spherical symmetry. Small spherical particles are attached to a fibrous surface, which can be ethylenediaminetetraacetate (Fig. 5). This indicates the stabilizing effect of EDTA.

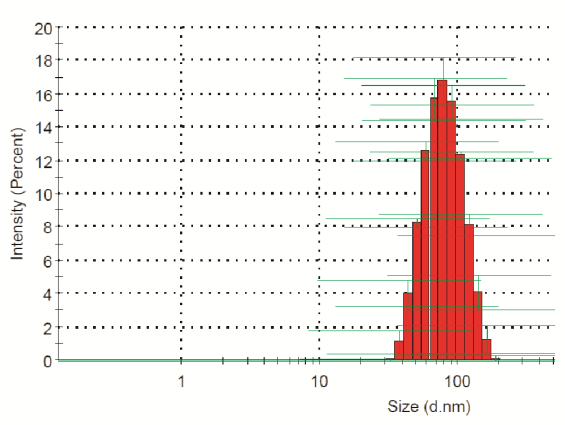

$a$

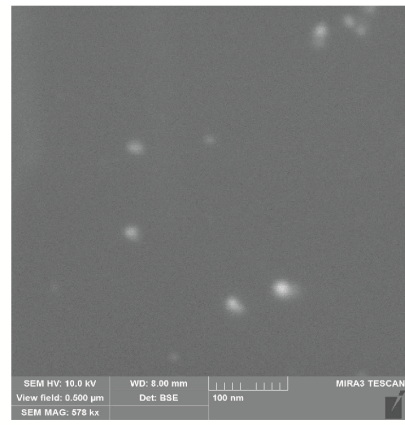

$b$

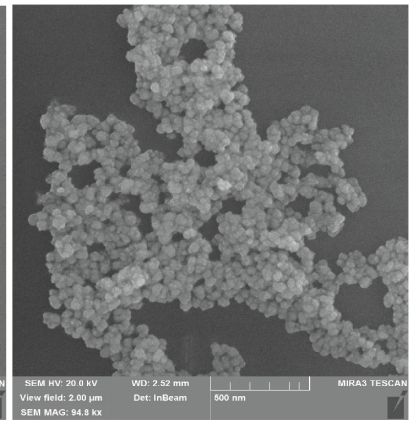

$c$

Figure 4 Distribution diagram and micrograph for systems (AgNO3): $\mathrm{Na}_{2} \mathrm{EDTA}, \mathrm{c}=0.005 \mathrm{M}$, scale mark $100 \mathrm{~nm}$ (b) $500 \mathrm{~nm}$ (c).

It is known that the method of physical condensation, namely the replacement of the solvent, allows the targeted control of the particle size. Therefore, it was of interest to precipitate complexonates with various solvents.

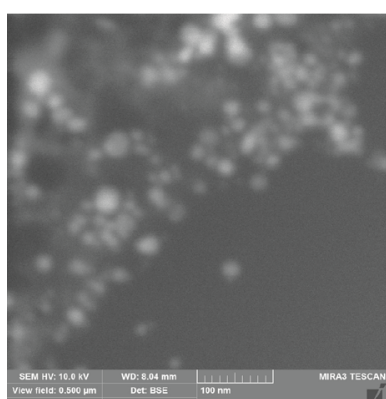

$a$

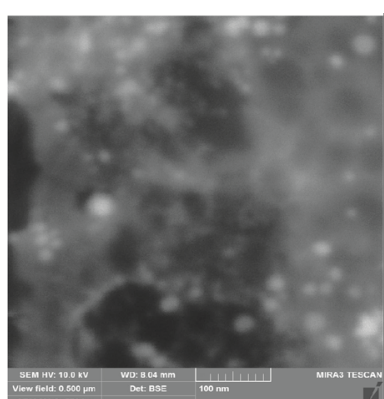

$b$
Figure 5 SEM micrographs of the test solutions, scale mark $100 \mathrm{~nm}$ (a) and $200 \mathrm{~nm}$ (b)

Already in the process of salting out, it was noticeable that the powder particles will have different shapes. So, when salting out from acetone, the particles simply settled to the bottom, like «classic» sediment or spherical particles, which precipitate under the action of gravity due to the violation of aggregative and sedimentation stability. The process of precipitation occurred fairly quickly. In the case of alcohol as a precipitant, the salting-out process was similar to a «blizzard» and was significantly extended in time.

Using the method of electron microscopy, it was shown that, depending on the solvent with which the complexes were precipitated, nanoparticles can have different shapes and sizes. Figure 6a shows micrographs of an AgEDTA powder obtained by precipitation from acetone, and in Fig. 6b, by precipitation from ethanol. When precipitated with acetone, the nanopowder particles have a spherical shape with layered surface morphology. The particle size is in the range of $20-33 \mathrm{~nm}$, which correlates fairly well with previous studies. Salting out the silver complexonate with alcohol makes it possible to obtain elongated particles. The 
micrographs of this powder are significantly different, since the particles are in the form of nanowires, and the surface morphology is fibrous, like the particles. The difference in the photomicrographs of the samples makes it possible to envisage different properties of the obtained complexonates.

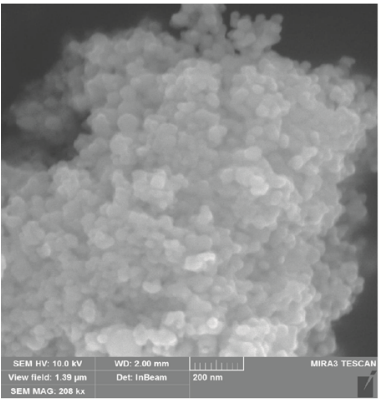

$a$

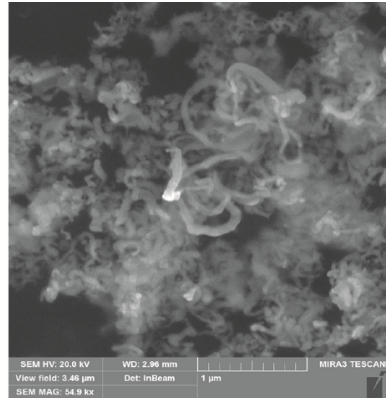

$b$
Figure 6 Photomicrographs of AgEDTA powder sample obtained by alcohol salting (a) acetone salting (b).

The antibacterial activity was studied using the example of a system containing spherical nanoparticles of AgEDTA, which was determined from the size of the formed inhibition zone concerning two types of pathogenic bacteria: Bacillus subtilis and Escherichia coli. After 72 hours of cultivation in an incubator at $37^{\circ} \mathrm{C}$, zones appear in the form of bright stains and transparent concentric circles around the disks with powder (Fig. 7). This indicates the effectiveness of the sample, in particular, inhibition of bacterial growth. In the culture medium of E. coli, a moderately pronounced zone of growth inhibition is observed, 0.5-3 $\mathrm{mm}$ in size (Fig. 7a). In the culture of B. subtiles, Fig. 7b, non-concentric zones, 2-10 mm in size, are very well pronounced.

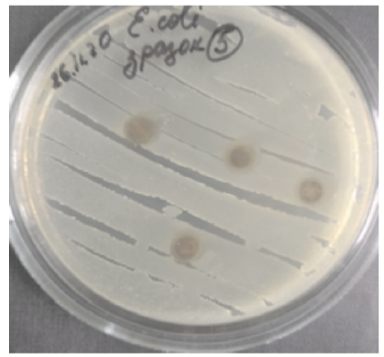

$a$

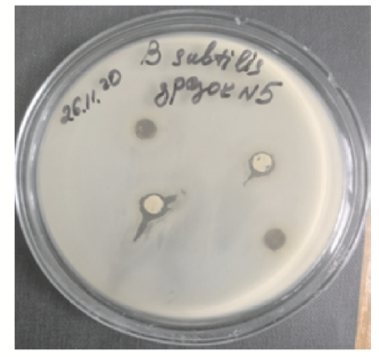

$b$
Figure 7. Inhibition zone size, against two types of pathogens: (a) E. coli UKM B-906, (b) B. subtilis UKM B-5006T.

\section{CONCLUSIONS}

AgEDTA complexonate, a nanodisperse system based on it, and a nanosilver solution have been obtained by the reduction of Argentum (I) nitrate with a $\mathrm{Na}_{2}$ EDTA solution were obtained. The particle size of the precipitated complexonate powder was in the range of $20-70 \mathrm{~nm}$ depending on the solvent used in the precipitation process. It has been found that the size and shape of the particles depend on the nature of the solvent precipitator. Studies of colloidal solutions have shown that reduction using EDTA allows one to obtain nanodisperse systems with a particle size of the dispersed phase of 10-30 $\mathrm{nm}$. Such systems are quite stable and do not require additional stabilization. We can assume that due to the low stability constant of silver (I) complexonate in both cases there are metal nanoparticles in the system. Metal nanoparticles are stabilized by the complex ion AgEDTA ${ }^{3-}$ in the case of complexonate, and in the case of colloidal solutions, the stabilizer is a solution of Na2edta. The particle size of AgEDTA powder is $20-50 \mathrm{~nm}$ when precipitated with acetone, and the diameter of the alcohol-precipitated nanowires is $25-65 \mathrm{~nm}$. The larger particle size of the powder compared to solutions $(10-30 \mathrm{~nm})$ is due to its conglomeration. 
Studies of biological activity have shown that the AgEDTA complex has insignificant antibacterial activity against gram-negative bacteria but proved to be quite effective versus gram-positive ones due to differences in the composition and thickness of the outer membrane of pathogens.

Thus, the studies show the effectiveness of the method of complexation and reduction of complexone to obtain stable highly disperse systems of silver.

The work was performed within the framework of the target program of basic research of the National Academy of Sciences of Ukraine "Prospective basic research and innovative developments of nanomaterials and nanotechnologies for the needs of industry, health care and agriculture" 31/20-H

\section{СИНТЕЗ ТА ВЛАСТИВОСТІ НОВИХ} НАНОСИСТЕМ АРґЕНТУМУ

Бережницька О. С. ${ }^{1,2}$, Семенів В. I. ${ }^{1,2}$, Сікорсъка К. А. ${ }^{2}$, Каменсъка Т. А. ${ }^{2}$, Хрокало Л. А. ${ }^{2}$, Трунова О. К. ${ }^{1}$

${ }^{1}$ Інститут загальної та неорганічної хімї ім. В. I. Вернадського НАН Украйни, просп. Академіка Палладіна, 32/34, Київ 03142, Україна

${ }^{2}$ Національний технічний університет Украйни "Київский політехнічний інститут" імені Ігоря Сікорського, просп. Перемоги, 37, Київ 03056, Украӥна

e-mail:olekberez@gmail.com
Синтезовано комплексонат AgEDTA, встановлено спосіб координації іону аргентуму (I) з функціональними групами комплексону. Різниця в положенні смуг валентних симетричних та асиметричних коливань карбоксильної групи свідчить про їхню монодентатну координацію до іону металу. Встановлено, що твердий комплекс осаджується 3 розчину у вигляді дрібнодисперсного порошку. Показано, що розмір та форма наночастинок порошку комплексонату аргентуму залежать від розчинника-осаджувача.

Отримано стійкі наносистеми двома шляхами: розчиненням твердого комплексонату та відновленням срібла розчином ЕДТА. Форма та положення смуг поверхнево плазмонного резонансу підтверджують наявність в обох дисперсних системах сферичних наночастинок розміром 15-30 нм. Звуження лінії та зростання інтенсивності смуги ППР свідчить про звикання дисперсних систем, а відсутність суттєвого зміщення максимуму смуги - про агрегативну та седиментаційну стійкість колоїдних розчинів. Положення максимуму та ширина смуги ППР розчину комплексонату та колоїдного розчину відрізнялися, що свідчить про різний розмір наночастинок. Методом електронної мікроскопії встановлено форму, дисперсність та морфологію отриманих наносистем. Показано, що AgNPs одержані методом відновлення, з використанням як відновлюваного агента розчину ЕДТА, мають сферичну форму, а їхній розмір знаходиться в діапазоні 10-30 нм. У випадку комплексонату AgEDTA розмір частинок порошку при осадженні ацетоном становить 20-50 нм, при осадженні спиртом діаметр отриманих нанодротів 25-65 нм. 
Діаграми розподілу дисперсних систем добре корелюють з електронними мікрофотографіями як щодо розподілу частинок, так і їхнього переважаючого радіусу.

Дослідження бактерицидної дії показали, що комплекс AgEDTA має незначну антибактеріальну активність проти грамнегативної бактерії, є ефективним проти грампозитивної, що зумовлено різницею складу та товщиною зовнішньої мембрани патогенів.

Ключові слова: наносистеми, срібло, комплексонат, EDTA, бактерицидна дія.

\section{REFERENCES}

1. Lee S.H., Sung J.H. Park, T.H. Nanomaterial-Based Biosensor as an Emerging Tool for Biomedical Applications. Annals of Biomedical Engineering. 2012. 40: 1384-1397.

2. Zhao G., Stevens SE Jr. Multiple parameters for the comprehensive evaluation of the susceptibility of Escherichia coli to the silver ion. Biometals : an International Journal on the Role of Metal Ions in Biology, Biochemistry, and Medicine. 1998. 1: 27-32.

3. Prabhu, S., Poulose, E.K. Silver nanoparticles: mechanism of antimicrobial action, synthesis, medical applications, and toxicity effects. International Nano Letters. 2012. 2: 32.

4. Pizent A, Tariba B, Živković T. Reproductive toxicity of metals in men. Archives of Industrial Hygiene and Toxicology. 2012. 63(1): 35-46.

5. Xu, L., Liu, Y., Chen, Z., Li, W., Liu, Y.,
Wang, L., Liu, Y.,. Wu, X., Ji, Y., Zhao, Y. Surface-engineered gold nanorods: promising DNA vaccine adjuvant for HIV-1 treatment. Nano Letters. 2012. 12(4): 2003-2012.

6. Pekkanen AM., DeWitt MR., Rylander MN. Nanoparticle enhanced optical imaging and phototherapy of cancer. Journal of Biomedical Nanotechnology. 2014. 10(9): 1677-1712.

7. Sosenkova, L.S., Egorova, E.M. The Effect of Particle Size on the Toxic Action of Silver Nanoparticles. Journal of Physics: Conference Series. 2011. 291.

8. Madeira JM, Gibson DL, Kean WF, Klegeris A. The biological activity of auranofin: implications for novel treatment of diseases. Inflammopharmacology. 2012. 20(6): 297-306.

9. Lee SH, Jun BH. Silver Nanoparticles: Synthesis and Application for Nanomedicine. International journal of molecular sciences. 2019. 20(4): 865.

10. Iravani S., Korbekandi H., Mirmohammadi SV., Zolfaghari B. Synthesis of silver nanoparticles: chemical, physical and biological methods. Res Pharm Sci. 2014. 9(6): 385-406.

11. Ramanathan S., Gopinath S.C.B. Potentials in synthesizing nanostructured silver particles. Microsystem Technologies. 2017. 23: 4345-4357.

12. Ortega F, Arce VB., Garcia MA. Nanocomposite starch-based films containing silver nanoparticles synthesized with lemon juice as reducing and stabilizing agent. Carbohydrate polymers. 2021. 252: 117208.

13. Jatoi A.W., Kim I.S., Ni QQ. A comparative study on synthesis of AgNPs on cellulose nanofibers by thermal treatment and 
DMF for antibacterial activities. Materials science \& engineering. C, Materials for biological applications. 2019. 98: 1179-1195.

14. M. Mehdi, M. Akhtar, S. Abro. Electrochemical synthesis of AgNP and mechanical performance of AgNP-EG coatings on soft elastomer. Journal of Elastomers \& Plastics. 2020. 52(7): 609-619.

15. Kokura S, Handa O, Takagi T, Ishikawa T, Naito Y, Yoshikawa T. Silver nanoparticles as a safe preservative for use in cosmetics. Nanomedicine. 2010. 6(4): 570-574.

16. Roy S., Shankar S., Rhim J. Melanin-mediated synthesis of silver nanoparticle and its use for the preparation of carrageenan-based antibacterial films. Food Hydrocolloids. 2019. 88: 237-246.

17. Shamsutdinova I.R., Derkho M.A. Features of biological action of silver nanoparticles in animals. Proceedings of the Orenburg State Agrarian University. 2016 1(57): 202-205.

18. Chekman I S., Priskoka A.O., Babiy V.F., Antonenko O.V., Zahorodniy M. I. Medical use of silver nanoparticles: toxicological Aspect. Modern problems of toxicology. 2010. 4: 10-13.

19. Stanishevskaya I.E., Stoinova A.M., Marakhova A.I., Stanishevskiy Y.M. silver nanoparticles: preparation and use for medical purposes. Drug development \& registration. 2016. 1: 66-69.

20. Srikar S.K., Giri D.D., Pal D.B., Mishra P.K. and Upadhyay S.N. Green Synthesis of Silver Nanoparticles: A Review. Green and Sustainable Chemistry. 2016. 6: 34-56.

21. Mousavi-Khattat M., Keyhanfar M., Razmjou A. A comparative study of stability, antioxidant, DNA cleavage and antibacterial activities of green and chemically synthesized silver nanoparticles. Artificial cells, nanomedicine, and biotechnology. 2018. 46(3): S1022-S1031.

22. Simakin A., Voronov V., Kirichenko N., Shafeev G. Nanoparticles produced by laser ablation of solids in liquid environment. Applied Physics A. 2004. 79: 11271132.

23. Abou El-Nour K.M.M., Eftaiha A., AlWarthan A., Ammar R.A.A. Synthesis and applications of silver nanoparticles. Arabian Journal of Chemistry. 2010. 3: 135-140.

24. Wiley B., Sun Y., Mayers B., Xia Y. Shape-controlled synthesis of metal nanostructures: the case of silver. Chemistry. 2005. 11(2): 454-63.

25. Landage S., Wasif A., Dhuppe P. Synthesis of nanosilver using chemical reduction methods. International Journal of Advanced Research in Engineering and Applied Sciences. 2014. 3: 14-22.

26. Bogacheva, N.V., Tarbeeva K.A., Ogorodova N.Y. Development of a step-by-step procedure for obtaining silver nanoparticles by the citrate method. Proceedings of higher educational institutions. Series «chemistry and chemical technology». 2020. 63(5): 65-69.

27. Semenenko V.A., Nabiullin A.R., Petrushenko L.G. Obtaining silver nanoparticles and research of their properties. International Scientific and Practical Conference of Students and Young Scientists. Actual problems of modern medicine and pharmacy. 2016. 70: 1122-1125.

28. Kolyada L., Medyanik N., Efimova Yu., Kremneva A. Synthesis and research of silver nanoparticles and the possibility of their use in food packaging. Vestnik MGTU im. G.I. Nosova. 2015. 2: 50. 
29. Bychkov A.L., Ryabchikova E.I., Korolev K.G., Bukhtoyarov V.A. Obtaining nanosized silver particles stabilized by hydrolysis products of yeast biopolymers. Vestnik VGUIT. 2019. 1: 79.

30. Nikolsky V.M., Pchelkin P.E., Sharov S.V., Knyazeva N.E., Gorelov I.P. Synthesis and application of complexones, derivatives of succinic acid, in industry and agriculture. Success of modern natural science. 2004. 2: 71.

31. Joanne S., Stephen D., David R. Chemical speciation of ethylenediamine- $\mathrm{N}, \mathrm{N}^{\prime}$-disuccinic acid (EDDS) and its metal complexes in solution. Chemical Speciation \& Bioavailability. 1999. 11: 3, 85-93.

32. Asemave K. Greener Chelators for Recovery of Metals and Other Applications. Organic \& Medicinal Chem IJ. 2018. 6(4): 555-694.

33. Schulz F., Homolka T., Bastús N.G., Puntes V., Weller H., Vossmeyer T. Little adjustments significantly improve the Turkevich synthesis of gold nanoparticles. Langmuir : the ACS journal of surfaces and colloids. 2014. 30(35): 10779-10784.

34. Fabrikanos, V. A., Athanassio, S., Liese, K. H. Darstellung Stabiler Hydrosole von. Gold und Silber durch Reduktion mit Äthylendiamintetraessigsaure. Z. Naturforschg. 1963, 18b: 612-23 617.

35. Dozol H., Mériguet G., Ancian B., Ca- buil V., Xu H., Wang D., Abou-Hassan A. On the Synthesis of Au Nanoparticles Using EDTA as a Reducing Agent. The Journal of Physical Chemistry C. 2013. 117(40): 20958-20966.

36. Dyatlova N.M., Temkina V.Ya., Popov K.I., Komplexones and complexonates. M.: Khimiya. 1988: 544. (in russian)

37. Barna A.W., Lampeka Ya.D. Influence of the chemical nature of polyoxometallate complexes on the flow of redox processes with the formation of nanoparticles of metallic silver. Theoretical and experimental chemistry. 2012. 48(4): 224-229.

38. Shevtsova V.I., Gaiduk P.I. Position of the surface plasmon resonance band in colloidal solutions of silver and gold nanoparticles. Vestnik BSU. 2012. 1(2): 15-18.

39. Motekaitis, R. J. Martell, A. E., Hayes, D., Frenier, W. W. The Iron (Iii)-Catalyzed Oxidation of Edta in Aqueous-Solution. Canad. J. Chem. 1980. 58: 1999-2005.

40. Bose, R. N.; Keane, C.; Xidis, A.; Reed, J. W.; Li, R. M.; Tu, H.; Hamlet, P. L. Oxidation of Ethylenediaminetetraacetic Acid by Permanganate Ion - a Kinetic-Study. Inorg. Chem. 1991. 30: 2638-2642.

41. Khan Z.; Raju, K.-U. D. Kinetics of Oxidation of Ethylenediaminetetraacetic Acid (EDTA) by Chromium (VI) in the Presence of Perchloric Acid. Indian J. Chem. Sect. B. 2004. 43(16): 149-156.

Стаття надійшла 27.02.2021. 